\title{
Vascular Permeability Alteration
}

National Cancer Institute

\section{Source}

National Cancer Institute. Vascular Permeability Alteration. NCI Thesaurus. Code C40864.

Vascular Permeability Alteration involves a qualitative change in the existing capacity of substances to pass from the vascular lumen, through a blood vessel wall, into surrounding tissue, or vice versa. 